\title{
Science-Policy Interactions in MPA Site Selection in the Dutch Part of the North Sea
}

\author{
Eline K. van Haastrecht • Hilde M. Toonen
}

Received: 9 October 2009/Accepted: 2 August 2010/Published online: 10 September 2010

(C) The Author(s) 2010. This article is published with open access at Springerlink.com

\begin{abstract}
At the 7th conference of the parties to the Convention on Biological Diversity (CBD-COP7, Kuala Lumpur, 2004) it was agreed to establish a global network of marine and coastal protected areas by 2012. The defined objectives of this MPA-network are based on the ecosystem approach: to protect biodiversity and other ecological values, and to ensure sustainable use. The (inter)national policy guidelines state that the selection of MPAs should be based on scientific information and ecological criteria only. As a signatory to the Convention, the Netherlands is now faced with meeting this obligation, and the process of designating the first Marine Protected Areas (MPAs) in the Dutch part of the North Sea is currently in progress. We focus on the science-policy interactions that are part of this Dutch MPA selection process. By taking a closer look at the contemporary site selection process as well as its historical background, we show that ecological, socio-economic and political considerations cannot always be easily separated. Uncertainty is high and the ultimate selection and delimitation of candidate sites rather seems to be the result of a balancing act between ecological, socio-economic and political interests, in which scientific and policy guiding procedures blend with ad-hoc political decision making, and with expert judgment in cases where data is
\end{abstract}

\section{E. K. van Haastrecht $(\square)$}

Amsterdam Institute for Social Science Research, University of Amsterdam, Kloveniersburgwal 48, Amsterdam 1012 CX, Netherlands

e-mail: e.k.vanhaastrecht@uva.nl

\section{H. M. Toonen}

Environmental Policy Group, Wageningen University and Research Centre, Hollandseweg 1, Wageningen, 6706 KN, Netherlands

e-mail: hilde.toonen@wur.nl lacking. As such, this paper presents an example of present-day environmental policy making in action.

Keywords Marine protected areas - Science-policy interface - Integrated marine management - Information . Expert judgment $\cdot$ North Sea $\cdot$ Netherlands

\section{Introduction}

The degradation of the marine environment is recognised as a central concern in sustainable development, and the continuing decline of many marine living resources has shown that the marine environment cannot be managed in terms of particular species (Pauly and others 2002). Over the past years, this has led to the realisation that broader ecological values such as biodiversity need to be taken into account (Worm and others 2006). As a result, a gradual shift has taken place, away from traditional fisheries management schemes, and towards the application of more holistic and integrated approaches to marine management (Hanna 1999; Apitz and others 2006). The widespread adoption of the ecosystem approach to marine management can be seen as the direct result of this synergistic shift in thinking: the aim is now not to protect individual species, but whole systems (e.g., Naeem 2002). The trend also links up well with broader objectives in sustainable development: while the ecosystem approach strives to take into account both structure and function of biological systems, it regards humans as a key system component. Another important characteristic of ecosystem-based management is that it tends to be place-based or area-based (Young and others 2007; Douvere and Ehler 2009). Accordingly, management efforts following the ecosystem approach have strongly focused on the implementation of protected areas, heralded 
'the cornerstones of biodiversity conservation' (e.g., Margules and Pressey 2000; Mulongoy and Chape 2004).

The idea that marine protected areas (MPAs) can form an important contribution to the conservation of marine biodiversity and other ecological values is reflected by a range of international policy arrangements and instruments. During the 2002 World Summit on Sustainable Development (WSSD 2002), governments agreed on the creation of a worldwide MPA network. A few years later, the 7th Conference of the Parties to the Convention of Biological Diversity (CBD-COP7, Kuala Lumpur 2004) subscribed to this goal and adopted the objective of supporting the establishment and maintenance of marine protected areas covering at least $10 \%$ of each of the world's eco-regions by 2012. The defined objectives of this MPA-network are based on the ecosystem approach. Signatories to the Convention are now faced with meeting this international obligation.

This article focuses on the contribution that is made by the Netherlands to the MPA network in the North Sea. The shallow, semi-enclosed North Sea is ecologically rich, but it is also one of the world's busiest seas, and a wide range of human activities impact its ecological values, including fishing, shipping, oil and gas extraction, energy production, military operations and the laying of cables and pipelines (Dotinga and Trouwborst 2009). Fishing in particular is considered to be the most significant human activity causing change, and reducing the resilience of the North Sea environment to other pressures, such as climate change (Ducrotoy and Elliott 1997; Zevenboom and others 2003). For example, studies have shown that $34 \%$ of the Dutch Continental Shelf area is trawled more than once a year, and that the impact on biodiversity in these areas is considerable (Lindeboom and de Groot 1998; Rijnsdorp and others 1998). Considering this intensive economic exploitation of the North Sea, there are many areas of likely conflict between nature conservation and the occurrence of human activities. However, while the Dutch approach to sustainable marine governance is characterized by the balancing of interests and providing maximum flexibility to economical interests, 'allowing as much scope as possible for private sector initiatives' (Douvere and Ehler 2009, p. 83), the international provisions prescribe that to ensure the ecological foundations of the future MPA network, site selection is to occur on the basis of scientific information and ecological criteria only (CBD-COP 7: Decision VII/28; EC 2007).

To augment the decision-making process towards the selection of these sites, policy makers (politicians and administrative officials) have turned to scientists for an ecological valuation of the marine environment. In this article, we will assess the science-policy interactions in the process of the designation of five candidate MPAs in the Dutch part of the North Sea. It should be noted that this discussion does not include MPAs that are located in internal waters (e.g. the Wadden Sea) but only covers those areas that extend to the North Sea. Our focus is on the role that scientific information has played in making policy decisions regarding these Dutch MPAs.

The Dutch case presents a good example of the processes surrounding the selection of MPAs in the European context. In contrast to well-known international examples of MPAs such as Australia's Great Barrier Reef, and Dry Tortugas and Channel Islands in the USA, European countries have to regulate and manage their MPAs more directly in accordance to a transnational context. Legally, the Dutch MPAs are to become part of the European wide Natura 2000 network, as well as linking up with other regional management schemes (e.g. OSPAR for the North East Atlantic). Other member states bordering the North Sea and other European seas are currently involved in similar processes (for a comparison on processes of marine spatial planning related to ecosystem-based sea use management, see Douvere and Ehler 2009).

In the next section, we will present a brief overview of notions on science-policy interactions, as provided in the social sciences, followed by a description of the relevant institutional context for marine management in the North Sea. Then, we continue with a discussion of the sciencepolicy interactions relevant to the process of MPA site selection in the Netherlands, and an analysis of the insights we gained from this exploration. We finish with the argument that while scientific information on the ecology of the North Sea has played an important role in initial site selection of Dutch MPAs, final delimitation of the five candidate sites seems to have been based on a wider and more complex set of considerations. These include the explicit anticipation of possible conflicts between nature conservation and (current and future) economic activities in the area, as well as an effort to link up Dutch marine spatial planning to larger international management plans. In cases where scientific uncertainty is high, or data are lacking, decision-making is facilitated by making use of expert judgment.

\section{Scientific Information in Policy Processes}

Dealing with complex environmental problems has made today's policy makers increasingly reliant on scientific advisors to supply them with knowledge about the systems they are trying to manage, and the role of scientific information in policy processes has been widely discussed among academics (e.g., Jasanoff 1990; Renn 1995; Halffman 2003; Yearley 2005; Pielke 2007; Mol 2008). Many studies refer to the frequently made distinction between fundamental science, on the one hand; and applied science (such as science-for-policy), on the other. The image that fundamental science-also referred to as 'pure' science- 
typically exudes is that of an objective and detached understanding of nature. Although this kind of science may often turn out to be useful or practical, this is not a goal in and of itself (Yearley 2005). Conversely, science-for-policy is usually produced in answer to specific questions, concerning particular sectoral or thematic spheres, or geographic regions. This type of applied, or advisory, science is typically highly contextualised and tends to be produced in more open systems of knowledge production (Gibbons 2000; Knol 2009). Reflecting the general trend in thinking about problems in light of the system they are part of, advisory science in the field of marine environmental management also tends to be of an integrated and interdisciplinary nature (Leslie and McLeod 2007).

To help the development of policies, scientists are called upon to answer questions regarding what elements of the environment should be protected, how it should be protected, and what human activities should be excluded to meet conservation goals (Turnhout 2003). Although scientific knowledge is typically seen as having a legitimating function in policy development, the integration of this specific science-for-policy in the policy process is far from unproblematic or straightforward. Marine science in particular is characterized by limited data availability, large uncertainties, and difficult and costly research and monitoring. Combined with a multiplicity of interests and conflicting ideas and values about what is considered good governance practice, information that is specific for the marine environment has certain attributes which complicate decision-making.

In general, a growing centrality of information and informational processes can be observed in today's environmental policy and decision making (Mol 2008). New governance arrangements come into play (Mol introduces the term 'informational governance'), with other actor constellations and steering modes, but also new ways of dealing with uncertainties and value-differences. Rather than looking only for (more) facts or 'hard data', expertise and experience are incorporated in the process, often in the form of expert judgment (Collins and Evans 2002). In contrast to information that is obtained through direct scientific experimentation or data-collection, expert judgment typically builds on implicit and undocumented reasoning, inferences, scientific convention, or even unconscious processes. Examples include (value) judgments on what data sources to draw upon, and interpreting and using the results for policy purposes (Otway and Winterfeldt 1992). Scholars investigating the role of experts have discussed expert judgment in relation to questions of legitimacy and accountability (Renn 1995; Collins and Evans 2002; Jasanoff 2003; Mol 2008). Jasanoff (2003), for instance, argues that it 'makes sense to look at expertise as a form of delegated authority, similar to the delegations that legislatures make to administrative agencies.' There are also risks attached to incorporating expert judgment in the sciencepolicy process. For instance, Renn (1995) argues that 'scientists acting under the expectation of providing unbiased, comprehensive and unambiguous advice [...] often fall prey to the temptation to over-sell their expertise and provide recommendations far beyond the realm of knowledge'. In some cases, expert judgment may border on intuition, or gut feeling, which may be of help in decision making in situations of high complexity and uncertainty (Dane and Pratt 2007), but which might also undermine the accountability of the process. While expert judgment is often drawn upon in more informal settings, organising expert judgment in a more formal way can have several advantages, such as revealing different opinions and disagreements, safeguarding transparency, and allowing others to review and understand it (Otway and Winterfeldt 1992).

As the (inter) national policy guidelines state that selection of candidate sites should be based on scientific information and ecological criteria only, scientists are placed at the heart of the MPA selection process. On the one hand, scientists are still seen as being the ones best able to provide objective information that helps improve the quality of policies; on the other, scientific authority in knowledge production is under debate (the so-called 'disenchantment of science' (Mol 2008); for instance, recall the recent 'Climategate' affair at the University of East Anglia's Climatic Research Unit), and scientific judgments are now often scrutinized and associated with vested interests (Yearley 2005). So, while close cooperation between science and policy is commonplace in dealing with environmental concerns, this partnership can threaten science's assumed impartiality, and there is a risk of delegitimization of policies that are based on scientific information concerning those aspects for which uncertainty is high.

By taking the selection of MPAs in the Dutch part of the North Sea as an example, we intend to focus on what happens in the exchange of information in such complex science-policy interactions in marine management. Although the MPA selection process comes in a rather conventional form of governance (i.e. compliance with international rules and regulations, emphasis on state authority, and dependence on science), information seems to play a formative role, and to constitute and structure governance practice (Mol 2008). In this sense, we view information not only as input, or resource, to the process (as part of a user-producer relationship between science and policy), but as something that may (re-) structure the practice of MPA selection.

Moreover, it seems that science-policy interactions not just revolve about the content of the information, but also 
become a matter of managing the process of information exchange. In the more context-sensitive and problem-driven practice of science-for-policy, what information means, or how it is valued, is shaped by the particular actors involved. In the close co-operations that ensue, the dividing line between the practice of science and that of policy making sometimes seems to blur. Although it would be too simple to say that the functional differentiation between science and policy making disappears, there is a dynamic coupling of the practices, in which some tasks are shared (see also Renn 1995; Weingart 1999).

\section{Institutional Context for Marine Management} in the Netherlands

On the international level, the WSSD (2002) and subsequent CBD agreements (CBD-COP7 2004, and after) can be considered the most important catalyser for the designation of MPAs all over the world. However, the protection of the marine environment in (the Dutch part of) the North Sea is subject to a range of other national, regional, and international agreements. As the Netherlands is an EU member state, Dutch environmental policy is to a large extent determined by European level institutions. Although the scope of this article does not allow a comprehensive overview of institutions applying to the Dutch situation, we will briefly introduce the European and national level institutions that are most relevant to our analysis. For a detailed overview of the legal context for MPAs in the Dutch context we refer to Dotinga and Trouwborst (2009).

\section{EU Level Institutions}

In the European Union, protected area management and implementation primarily take effect through Natura 2000, a policy programme first established in 1992. Natura 2000 builds on the provisions in the 1979 EU Birds and 1992 EU Habitats Directives (BHD), and consists of Special Protection Areas (SPAs) designated under the Birds Directive, and Special Areas of Conservation (SACs) designated under the Habitats Directive. In their annexes, the BHD provide lists of (a limited number of) marine habitats and species qualifying for protection (see Table 1).

The Natura 2000 network forms the EU's main contribution towards meeting the 2012 obligations to the CBD, but while it is well developed for terrestrial and coastal environments, efforts to include marine areas beyond the coastal zone have only recently begun (UNEP-WCMC 2008). Important to note is that for the selection and delimitation of sites under the Birds and Habitats Directives, it is stated that member states are to employ scientific data and ecological criteria only. This is made explicit in the European guidelines to the MPA selection procedure:
Table 1 Selection criteria (species and habitats) under the Birds and Habitats Directives relevant for the North Sea (adopted from Lindeboom and others 2005)

Birds directive (Annex I species)

Black-throated diver; red-throated diver; great northern diver; Slavonian grebe; storm petrel; Leach's Petrel; Balearic shearwater; little gull; Sandwich tern; common tern; Arctic tern; little tern; black tern

Habitats directive (Annex I habitats)

Sandbanks permanently submerged by seawater (Habitat type 1110)

Reefs (Habitat type 1170)

Submarine structures formed by leaking gasses (Habitat type 1180)

Habitats directive (Annex II species)

Marine mammals: grey seal; common seal; bottlenose dolphin; porpoise

Fish: river lamprey; sea lamprey; alis shad; twaite shad; sturgeon

The obligations of Member States [...] [are] to ensure that the site designation process is exclusively based on scientific criteria. As regards areas to be protected under the Birds Directive, the Court of Justice has emphasised that the selection of sites and the delimitation of boundaries should be carried out on the basis of exclusively ornithological criteria. As regards the Habitats Directive, case law confirms that site selection by Member States should be exclusively based on the ecological criteria of Annex III of the directive. Therefore, future management challenges should not be a determining element in this process (EC 2007, p. 21).

The regional sea convention of OSPAR (the combined Oslo and Paris Conventions for the North-East Atlantic) meanwhile aims to establish a network of MPAs in the North Sea by 2010. Although OSPAR works on the basis of different lists of threatened species and critical habitats, these do link up partially to the Natura 2000 targets.

Important regional support is further provided by the Bergen Declaration, adopted by the North Sea ministers at the Fifth Conference on the Protection of the North Sea (Norway 2002). The Bergen Declaration reaffirms the agreements made within the context of OSPAR and explicitly proposes Natura 2000 to function as a framework. The Bergen Declaration also includes a strong call for scientific information to serve as cornerstone in the site selection process.

In addition, the cross-sectoral European Marine Strategy Framework Directive (MSFD 2008) will provide an important political framework for marine management in Europe in the coming years. Its main objective is delivering Good Environmental Status (GES) of European seas by 2020, in which the implementation of MPAs is seen as an 
important tool (Christiansen 2009; Dotinga and Trouwborst 2009). While the directive contains a strong environmental pillar for European marine policy, it is also designed to anticipate on future economic developments at the European seas.

\section{National Level Institutions and Instruments}

The EU-level targets need to be implemented at the national level. However, while in the Netherlands species and habitat protection is legally organised under the Flora and Fauna Law and the Nature Protection Law, provisions have been added to incorporate the BHD in the latter, and Dutch Natura 2000 areas will be integrated in the National Ecological Network. Important to note is that, while in general MPAs exist in different shapes and sizes and there is great variation with respect to their objective and the extent of protection (ranging from the exclusion of all human activity, to allowing specific economic or recreational activities), the Natura 2000 areas are explicitly geared towards multiple-use, in which natural values are managed in concurrence with socio-economic exploitation (Hugenholtz 2008).

At the national level, there is consequently a growing call for a more integrated approach to marine management, and an important role is played by the Interdepartmental Directors Consultative Committee North Sea (IDON). IDON replaced the earlier Interdepartmental Coordinating Committee for North Sea Affairs (ICONA) in 1998 and brings together six ministries. Although activities concerning the North Sea have traditionally been regulated following a sectoral zoning approach (e.g., shipping lanes, no-take zones around oil rigs, military zones), the more integrated approach that is now preferred, is facilitated by the joint character of IDON. The 2005 'Integrated Management Plan for the North Sea 2015' is a result of this joint approach to marine management, and can be regarded a significant first step in the direction of applying ecosystem-based management to the Dutch marine environment (IDON 2005). However, while in the management plan reference is made to the proposed MPAs, no indications of restrictions for existing activities in these selected areas are proposed. This is re-emphasized in the National Water Plan for the years 2009-2015, in which it is stated that although the selection of MPAs should follow the ecosystem approach and meet the provisions under (inter)national law, future activities of large socio-economic importance should not be restricted within protected areas (NWP 2009). Activities that are specifically mentioned in this context are oil, gas and sand extraction, $\mathrm{CO}_{2}$ storage, and wind energy parks (NWP 2009, p. 213). Currently, different working groups are in the process of discussing measures to manage potential conflicts in terms of marine environmental protection and multiple-use, and a number of studies and management plans investigate how the actual implementation of MPAs can be facilitated (e.g., PBL 2008; Jak and others 2009).

\section{Current Status of the Dutch MPA Network}

The current status of MPA selection in the Dutch part of the North Sea is that the Netherlands have nominated five sites under the Bird and Habitat Directives in December 2008:

- Dogger Bank (Doggersbank; Habitats Directive);

- Cleaverbank (Klaverbank; Habitats Directive);

- Vlakte van de Raan (Habitats Directive) in the $12 \mathrm{~nm}$ zone;

- Frisian Front (Friese Front; Birds Directive); and the

- Northern Coastal Zone between Bergen and the German border out to the $20 \mathrm{~m}$ isobath (extension of the $\mathrm{SAC}$ in the Coastal Zone of the Wadden Sea) (Kustzee; Birds and Habitats Directives).

These sites (see Fig. 1; the shaded areas are the proposed areas) will be designated as protected areas as part of the European Natura 2000 network in 2010 (provided the EC accepts the nominations). These same areas have been nominated as OSPAR MPAs.

Some of the nominated areas are extensions of areas that already are under protection. The Vlakte van de Raan, bordering the Voordelta (the southern Coastal Zone), already has protective status (Birds and Habitat Directives), as well as the Coastal Zone of the Wadden Islands (Northern Coastal Zone), which will be extended to the $20 \mathrm{~m}$ isobath. Selection under the Birds Directive is still under way (i.e. the Frisian Front has not yet been designated as a SPA, and additional sites might yet qualify). Additional areas that have not been designated as MPAs (but might be) are: Bruine Bank, Borkumse Stones, Gas Fountains, Central Oyster Grounds, and a part of the Coastal Zone (marked areas in Fig. 1). These additional sites are areas of which research has indicated special ecological values (Lindeboom and others 2005), but about which decision-making has been postponed. New research in these areas has been initiated (e.g., Witbaard and others 2008).

Science-Policy Interactions in the Dutch MPA Selection Process: Three Phases

Although the Netherlands did not formally commit itself to the establishment of protected areas in the North Sea until the early 2000s, early initiatives date back some twentyfive years. This specific historical context sheds an interesting light on contemporary selection processes, and we 
Fig. 1 Proposed areas with special ecological values at the Dutch Continental Shelf (adopted from IDON 2005, map 12)

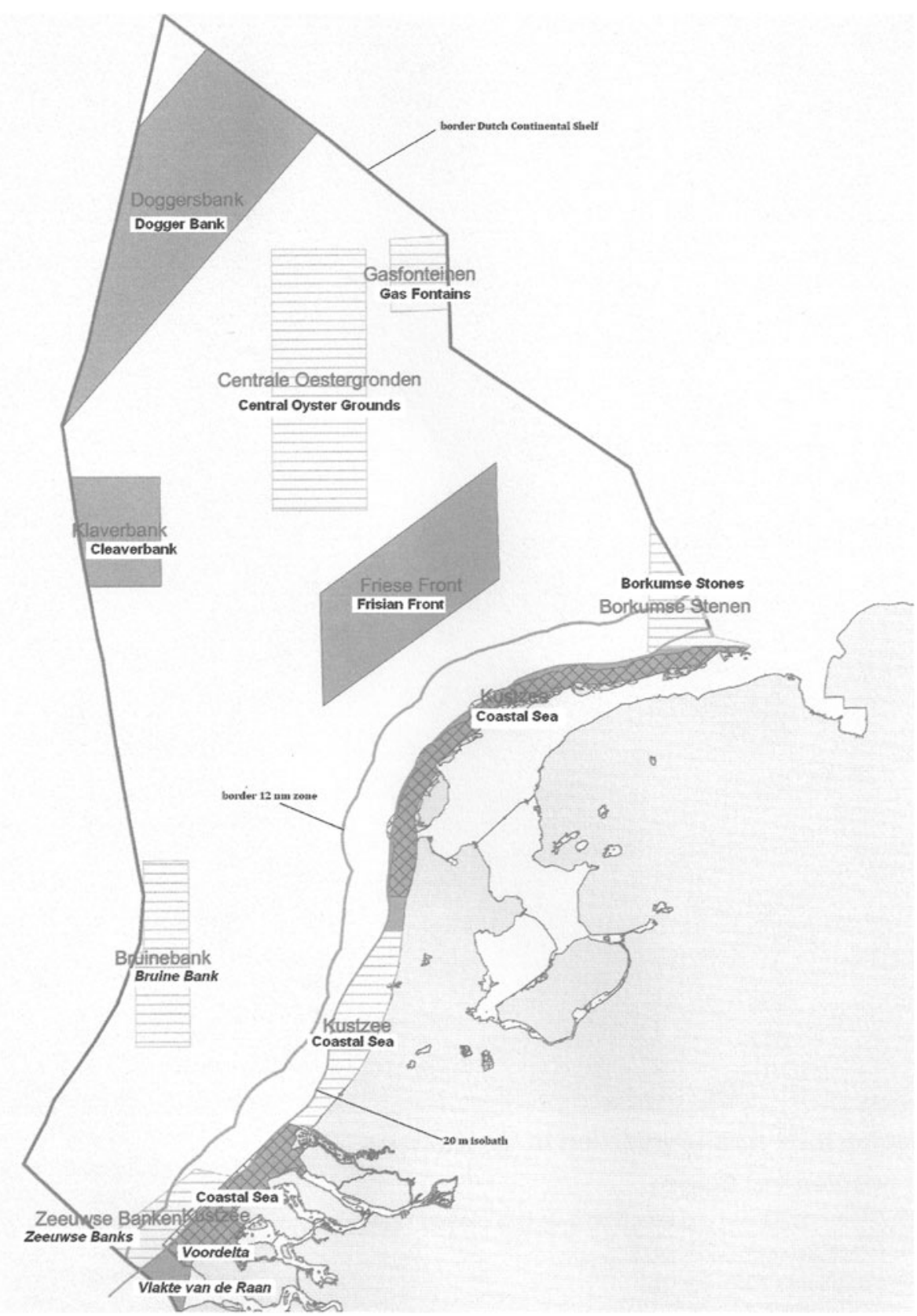

will describe the actions in this period, for which a clear distinction can be made into three stages.

The discussion presented in this section is based on documentary research of key reports on marine protected areas (or area-based marine conservation) in the Netherlands of the last twenty years (see Table 2 for an overview). Additional information to clarify and complement the documentary analysis was collected during a number of semi-structured interviews with key scientists and policy makers ( $\mathrm{n}=10$, details can be requested from the authors). The research has further benefited from ongoing participant observation in various meetings regarding MPA site selection and area-based management in the Dutch part of the North Sea.

\section{Early Initiatives: 1980s-Early 1990s}

In the $1980 \mathrm{~s}$, concerns over the marine environment concentrated mainly on eutrophication and pollution by accidental spills. Within international fora, such as the International Maritime Organisation (IMO), the establishment of protected areas was debated, but mainly from a maritime safety point of view (e.g., in the context of shipping lanes) (Freestone and IJlstra 1990). Slowly but 
Table 2 Overview of key reports on marine protected areas (or area-based conservation) in the Netherlands (1989-2005)

\begin{tabular}{|c|c|c|c|}
\hline Year & English title (Dutch title) & Type of document & Prepared by/reference \\
\hline 1989 & $\begin{array}{l}\text { Nature Protection Policy Plan } \\
\text { (Natuurbeleidsplan) }\end{array}$ & Policy plan & $\begin{array}{l}\text { Ministry of Agriculture, Nature and Fisheries } \\
\text { (Landbouw, Natuurbeheer en Visserij- } \\
\text { LNV) }\end{array}$ \\
\hline 1990 & $\begin{array}{l}\text { Area protection at the North Sea } \\
\text { (Gebiedsbescherming op de Noordzee) }\end{array}$ & Scientific report (law) & IJlstra and Nollkaemper 1990 \\
\hline 1991 & $\begin{array}{l}\text { Protected Areas North Sea (Beschermde } \\
\text { Gebieden Noordzee) }\end{array}$ & Scientific report (ecology) & Bergman and others 1991 \\
\hline 1992 & $\begin{array}{l}\text { North Sea atlas for Netherlands policy and } \\
\text { management (Noordzee-atlas voor het } \\
\text { Nederlands beleid en beheer) }\end{array}$ & Reference document & ICONA \\
\hline 1992 & $\begin{array}{l}\text { Environmental Zoning of the Dutch Continental } \\
\text { Shelf; Based on ecosystem features }\end{array}$ & Reference document & $\begin{array}{l}\text { Ministry of Transport, Public Works and } \\
\text { Water Management (Verkeer en } \\
\text { Waterstaat-V\&W) }\end{array}$ \\
\hline 1993 & $\begin{array}{l}\text { The North Sea: a sea of space? (De Noordzee, } \\
\text { een zee van ruimte?) }\end{array}$ & Report of symposium & ICONA \\
\hline 1994 & $\begin{array}{l}\text { Environmental impact of bottom gears on } \\
\text { benthic fauna in relation to natural resources } \\
\text { management and protection of the North Sea }\end{array}$ & Scientific report & de Groot and Lindeboom 1994 \\
\hline 1998 & $\begin{array}{l}\text { The effects of different types of fisheries on the } \\
\text { North Sea and Irish Sea benthic ecosystems }\end{array}$ & Scientific report & Lindeboom and de Groot 1998 \\
\hline 1999 & $\begin{array}{l}\text { Management plan North Sea } 2010 \text { (Beheersvisie } \\
\text { Noordzee 2010) }\end{array}$ & Policy plan & $\begin{array}{l}\text { Ministries of V\&W, LNV, Economic Affairs } \\
\text { (Economische Zaken-EZ) and Housing, } \\
\text { Spatial Planning and the Environment } \\
\text { (Volkshuisvesting, Ruimtelijke Ordening } \\
\text { en Milieubeheer-VROM) (Stuurgroep } \\
\text { Beheersvisie Noordzee 2010) }\end{array}$ \\
\hline 2002 & $\begin{array}{l}\text { Nature Values Map North Sea } \\
\text { (Natuurwaardenkaart Noordzee) }\end{array}$ & Knowledge document & Van Berkel and others 2002 \\
\hline 2004 & $\begin{array}{l}\text { National Spatial Planning Policy Document } \\
\text { (Nota Ruimte) }\end{array}$ & Policy plan & $\begin{array}{l}\text { Ministry of VROM, in cooperation with } \\
\text { ministries of V\&W, LNV, and EZ }\end{array}$ \\
\hline 2005 & $\begin{array}{l}\text { Areas with special ecological values on the } \\
\text { Dutch Continental Shelf }\end{array}$ & Scientific report (ecology) & Lindeboom and others 2005 \\
\hline 2005 & $\begin{array}{l}\text { Integrated Management Plan for the North Sea } \\
2015 \text { (Integraal beheerplan Noordzee 2015) }\end{array}$ & Management plan & IDON 2005 \\
\hline
\end{tabular}

surely though, the topic gained attention, and both Dutch policy-makers and scientists took the subject on board.

Early ideas about applying area-based management instruments for the protection of marine species in the Dutch part of the North Sea date back to the middle of the 1980s, and in the following years several ecological studies and impact assessments were carried out. In 1989 the Dutch Ministry of Agriculture, Nature and Fisheries (Ministerie van Landbouw, Natuurbeheer en Visserij, hereafter: Ministry of LNV) launched a project as part of the Nature Protection Policy Plan called 'Protected areas in the North Sea'. This project consisted of two separate studies to investigate the possibilities for area based management for the marine environment: one to explore the jurisdictional and policy options, and another concerning the ecological aspects of such an approach. The first study (IJlstra and Nollkaemper 1990) concluded that it was legally feasible to establish protected areas, although only by means of a complicated mixture of national and international law. Until then, the regulation of human activities on the North Sea was mainly executed under the flag of the EU Common Fisheries Policy, or by global bodies such as the IMO (primarily focused on shipping and pollution). This institutional constellation did not provide the most suitable framework in which to manage the marine environment at a national level, at which environmental concerns needed to be balanced with a variety of socioeconomic interests. In order to facilitate the future implementation of MPAs, the study therefore recommended the transfer of greater jurisdictional power to the national level by the establishment of a Dutch Exclusive Economic Zone (EEZ) (ibid.: 142). The ecological study (Bergman and others 1991), conducted by researchers of the Royal Netherlands Institute for Sea Research (NIOZ), described the distribution and abundance of plankton, benthos, fish, sea birds and sea mammals. In addition, they addressed the 

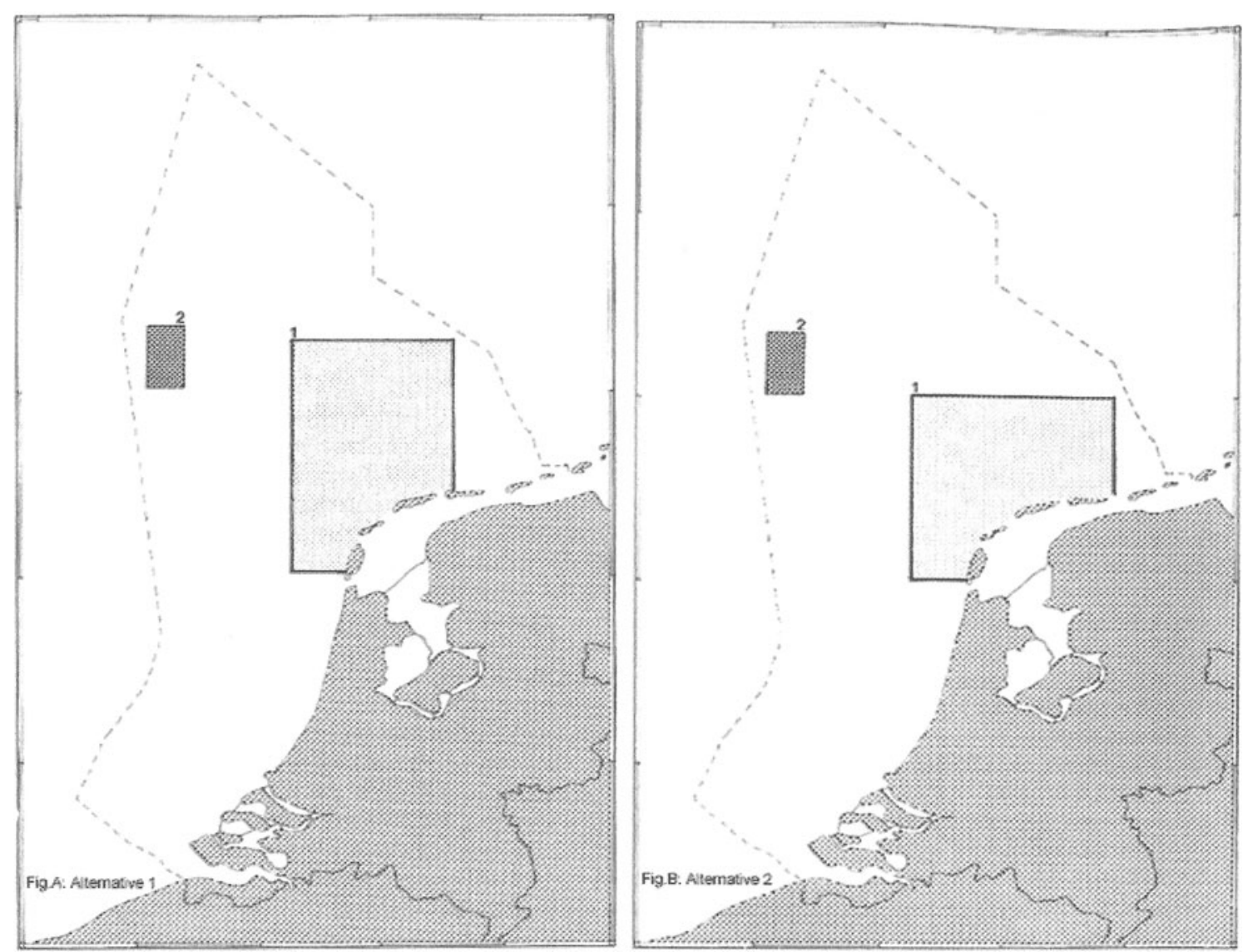

Fig. 2 Alternative maps 1 (left) and 2 (right) depicting early proposals for areas within the Dutch sector of the North Sea qualifying for a protected status (adopted from Bergman and others 1991, p. 6)

effects of human activities on the marine ecosystem, and they proposed several protective measures, such as minimizing or prohibiting use in certain areas. Two maps were presented in this study, pointing to areas that could be eligible for protection (see Fig. 2). Both alternatives propose the Frisian Front and the area directly northwest of the Frisian Islands (area 1, of which the shape is slightly different in each alternative), and the Cleaverbank (area 2).

Important to note is that this was not only interplay between scientists and policy-makers. There was a strong combined lobby of several of the Dutch environmental NGOs at the time, lead by the Working Group North Sea, the predecessor of the present North Sea Foundation (Stichting de Noordzee) and the Wadden Sea Foundation (Waddenvereniging). These NGOs sought cooperation with marine scientists to provide supporting evidence for their cause, which eventually led to a more active involvement of scientists in the policy process as well. In the years to follow, environmental NGOs continued to fuel the debate.

At this time, both scientists and policy makers seemed keen on taking further steps towards the implementation of area-based environmental management measures in the North Sea, and a debate started to emerge about the possible introduction of so-called environmental zones (" $\mathrm{mi}$ lieuzones') in the North Sea (ICONA 1993). The implementation of such zones would mean the closing off of certain areas to specific human activities, and were primarily aimed at diminishing effects from fisheries and oil pollution from offshore industry. To facilitate policy making, a North Sea Atlas (ICONA 1992) was compiled, making available combined scientific information on abundance and distribution of zoobenthos, fish, sea birds and sea mammals, but also including maps of human activities at sea. On the basis of these studies, the first more formal suggestions were made about possible locations for environmental zones, or marine protected areas (V\&W 1992). The reference document highlights the Coastal Zone, Frisian Front, and Cleaverbank as priority areas, alongside several of the other sites that are still being discussed today. The report also includes a map (see Fig. 3) that shows the proposed area as one interconnected zone (the shape of which caused our respondents to refer to this particular map as the 'pistol shaped map') (Ibid.). 


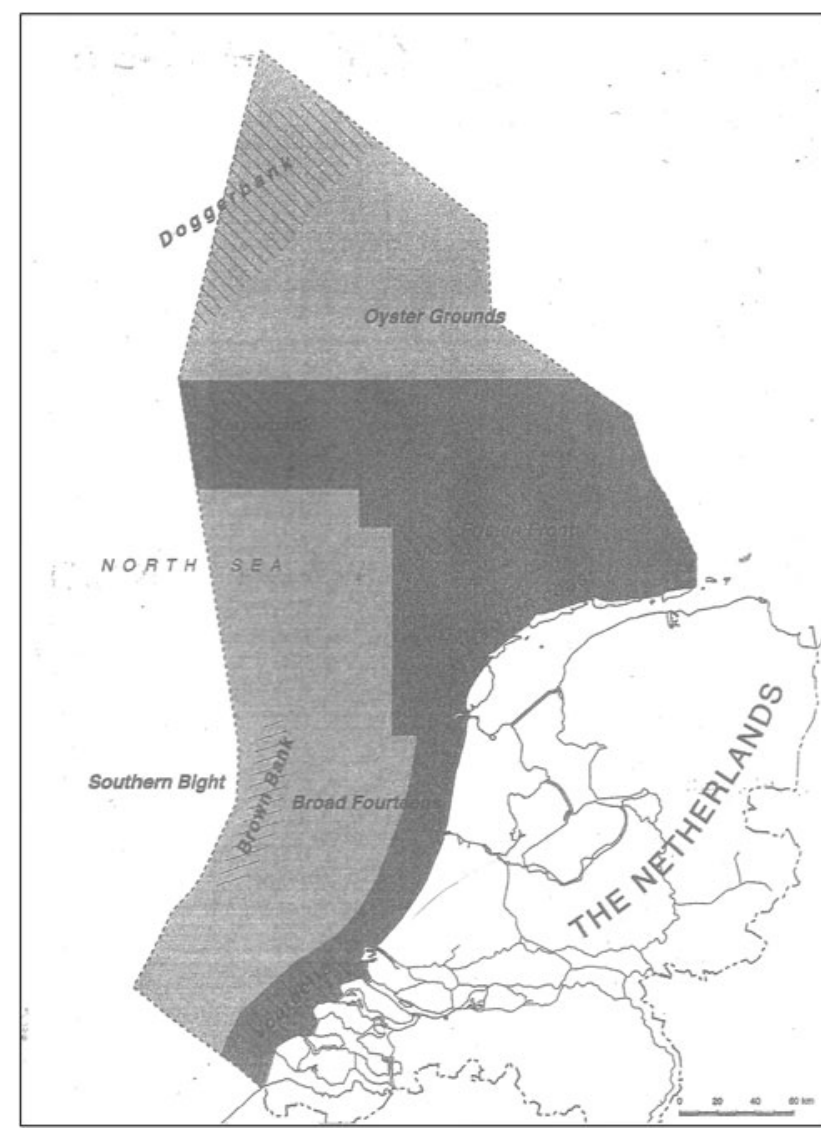

Fig. 3 'Pistol-shaped map' (an interconnected area of the Coastal Zone, Frisian Front, and Cleaverbank) (adopted from V\&W 1992, front page)

Reduced Interest and Another Attempt:

Mid 1990s-2002

After this first period of interest in area-based management measures in the Dutch part of the North Sea, attention drifted away. Although a series of scientific studies on the impact of fisheries on the marine ecosystem was carried out (de Groot and Lindeboom 1994; Lindeboom and de Groot 1998), there was a lack of political interest. The feasibility of applying area-based management measures in the North Sea depended to a large extent on the expansion of national jurisdiction, but the implementation of an EEZ in Dutch waters had not yet taken place. Next to that, fishermen began to grumble about the possible closure of certain areas at sea. At that time, the minister of LNV also had a hard time dealing with the agricultural sector and decided to go slow on the issue of protected areas. So, despite the earlier efforts, no further action was taken at this moment towards the actual designation of sites. This is illustrated by the fact that the 1998 Dutch policy document on the North Sea (Beheersvisie Noordzee 2010) did not even refer to the possibility of protecting marine biodiversity by closing certain areas.

Several policy makers emphasized that in policy making 'the time has to be right'. As one interviewee put it: 'in policymaking, there is often a delay between stating a problem and dealing with it. Policy makers of the different departments involved did not see how this topic was linked to their own field. It took some years for them to realize what they had to do with it'. In that sense, the case of protected areas at sea was not unlike other policy issues, although probably somewhat more challenging because it had to be dealt with in and between different departments. One of the administrators stated: 'Whether a project such as this is taken up depends on creating support among all involved parties, as well as a shared sense of urgency'.

In any case, interest for area-based nature conservation in the Dutch part of the North Sea did not pick up again until a few years later. The new impulse to the process was given by the fact that in 1997 the EU decided that Natura 2000 provisions also applied to the EEZ of member states, and in 1998, Greenpeace threatened the UK government with court action, because it did not comply with the Habitats Directive in its EEZ. In the Netherlands, this was felt as a warning of imminent complications in marine spatial planning and created a sense of urgency that action needed to be taken. In the same year, the joint-ministerial body of IDON was established to enhance more effective coordination of North Sea affairs. In 1999, policy-makers began to work on the project 'Ecosystem Goals North Sea' (Ecosysteemdoelen Noordzee), which aimed at a better integration of nature conservation in North Sea policy. In 2000, the national EEZ was implemented (IJlstra and Nollkaemper 1990; Dotinga and Trouwborst 2009).

In 2002, the ministry of LNV (directorate for Nature) published a knowledge document 'Nature Values Map North Sea' (Natuurwaardenkaart Noordzee) (Van Berkel and others 2002). This document presented a map of areas of special ecological value, indicating the Coastal Zone the Frisian Front, the Cleaverbank, the Dogger Bank and the Central Oyster Grounds (see Fig. 4). This map was heavily debated within the ministry of LNV, illustrative of the tensions between its directorate for Nature and its directorate for Fisheries. Other ministries also mingled in the debate, because of possible spatial conflicts with economic activities, such as shipping, oil and gas production, and sand extraction. However, the subsequent resignation of the cabinet in the same year (due to other political issues) brought the developments again to a standstill, and there was no direct follow-up on the outcomes of the mapping exercise. 
Fig. 4 Integrated Nature Value Map North Sea

(Natuurwaardenkaart

Noordzee). The shading on the map corresponds to the assigned 'nature value' (based on marine biodiversity) of the particular areas. The coastal zone has a value of 6 (highest possible value); the dark shaded area (including the Frisian Front): 4; Dogger Bank and Cleaverbank: 3 ; and the area including the Central Oyster Grounds: 2 (adopted from Van Berkel and others 2002 , p. 50)

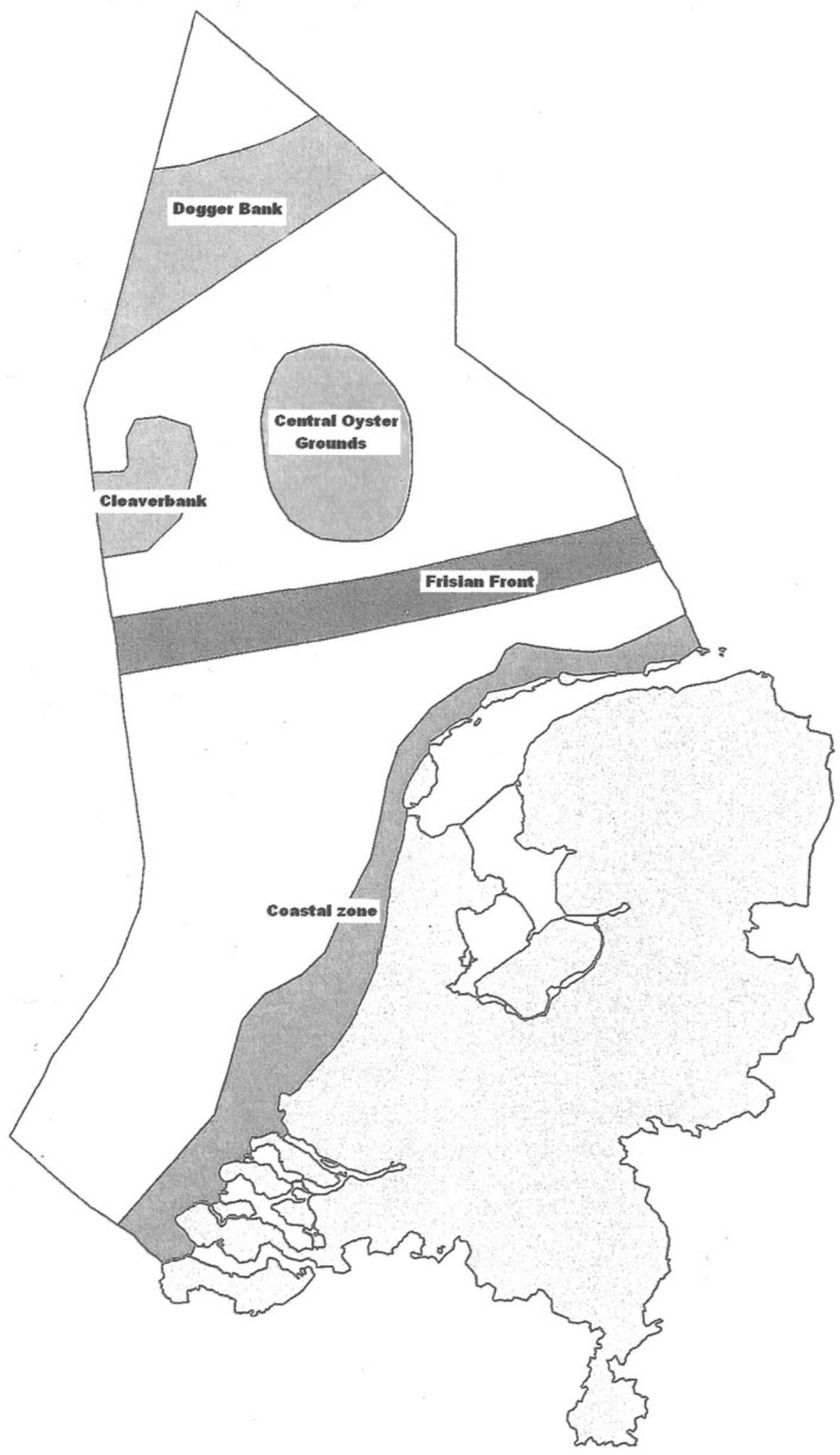


Formal Selection Procedure: 2004 and Onwards

Two years went by before the process picked up speed again. The 2002 Bergen Declaration, along with the commitments made to the international community, eventually led policy-makers to take up the project again with renewed energy, aware of the fact that this time the Netherlands would have to meet the international requirements. In 2004, to support the process of site selection, the ministry of LNV and the ministry of Transport, Public Works and Water Management (Ministerie van Verkeer en Waterstaat; $V \& W)$ requested an ecological evaluation of the North Sea. The explicit aim of this evaluation was to formally assess the boundaries of five areas that were indicated in the 2004 National Spatial Strategy (Nota Ruimte; map 10: 163) as possible locations for protected area management. Interestingly, these areas were identicalalthough represented in a different layout - to the ones put forward in the earlier and heavily contested Nature Values Map (Van Berkel and others 2002). In light of the new obligations to the EU after the installation of the national EEZ, the responsible ministries needed to know to what extent these specific areas met the provisions of the BHD.

The study resulted in the report 'Areas with special ecological values on the Dutch Continental Shelf' (Lindeboom and others 2005), which presented data on the occurrence of habitats mentioned in the Habitat Directive and on the distribution and abundance of benthos, fish, sea birds and sea mammals, along with maps of current and future human activities in the Dutch part of the North Sea. Although the evaluation concentrated on the five preselected areas mentioned above, the involved scientists got the explicit freedom to mark additional areas of high or special ecological values (Lindeboom and others 2005, p. 67). However, no new ecological information was produced within the scope of the study, and the evaluation of candidate sites was carried out using only existing information (Lindeboom and others 2005, p. 14). This information was not abundant, and contained uncertainties: the distribution of monitoring stations did not fully cover all areas possibly qualifying for protection, and there had been no or only sporadic sampling in some sites (e.g. the southern part of the Coastal Zone). In cases where data was lacking, scientists were asked for their expert judgment. This kind of expert judgment was seen as an inevitable part of the evaluation process, mostly because marine research and monitoring is well-known to be both complicated and costly. In these cases scientists typically used deductive reasoning to support their advice (e.g. based on irregular data, combined with knowledge of neighbouring areas, assumptions were made on the character of the site under enquiry). However, respondents from the policy field reported of being aware that there was a certain risk in using this kind of input in the selection of sites. Expert opinion may at times hide more personal concerns and interests, which could result in a different interpretation of findings. Nevertheless, the decision making process continued to rely heavily on the ecological argumentation as provided by science, and policy makers underscored their trust in scientific judgment by referring to the system of quality control within the scientific community itself: 'the scientists involved are internationally renowned and their work is peer reviewed'.

While the Dutch government was committed to base the designation of areas on scientific information on ecological values, Lindeboom and others (2005) explicitly took into account the spatial distribution of current and future human activities. This information was included in the report to anticipate potential conflicts between nature conservation and socio-economic activities. The impact of human activities on ecological values was further discussed during a series of expert meetings, which were attended both by scientists and policy makers from all departments involved. The workshops resulted in elaborate impact tables that valued effects in terms such as 'positive', 'marginally negative', and 'considerably negative' (Lindeboom and others 2005, pp. 83-99). Another point of discussion during these workshops was the setting of site boundaries. The report concluded with a proposal for the designation of all five areas as MPAs. Nevertheless, the Dutch government decided to designate only four areas, leaving the Central Oyster Grounds out on the basis of the argument that although this silt-rich area met the OSPAR criteria (on the basis of high benthos biodiversity), it did not meet the more narrowly defined requirements of the BHD (see Table 1; Lindeboom and others 2005, p. 59)

\section{Analysis: The Role of Scientific Information in Dutch MPA Selection}

We have described the MPA selection process in the Dutch part of the North Sea to gain more understanding into the role of scientific information in marine management and policymaking in the Netherlands. Most important with respect to the formal requirements applying to the Dutch situation is that the Dutch MPAs are to be included in the European-wide Natura 2000 network of protected areas. Legally, this means that candidate sites need to meet the ecological criteria as stipulated in the Birds and Habitats Directives, and that the selection of sites should not be determined by concerns over future management (EC 2007).

The key scientific report ordered by the Dutch government to explore the eligibility of sites (Lindeboom and others 2005) specifically looked at the extent to which a pre-defined set of proposed areas would meet the BHD 
criteria. In this sense, the international and European requirement that ecological criteria should form the basis to the MPA selection process seems to have been met. However, it is too simple to say that the selection is the straightforward outcome of a well-structured and unproblematic process involving a user-producer relation between science and policy. While in theory the 2005 report is the result of a clear-cut request for information from policy makers to scientists, there is a tension between the formulated guidelines and the practice of the designation process. The empirical part of this article shows a process of information exchange in science-policy interactions in which the approach is and has been very context-sensitive: from the beginning, area-based management initiatives linked ecological information to the context of application (taking into account a diverse set of interests and demands).

Although the formal selection procedure leading up to the recent nomination of the first sites took place only in the last few years, the early beginnings of the process clearly reflect a longer-term desire to implement area-based management measures in the Dutch part of the North Sea, and the particular outcome of the contemporary selection process seems to build directly on initiatives that failed at earlier moments in time. Moreover, as the current selection of sites is based on data-sets and studies that (for the most part) have been available for many years (see Table 2), it seems that rather than by a lack of scientific information (a popular argument to explain a lack of action), discontinuity in the process was caused by political reasons. Only when the Netherlands was faced with a growing sense of urgency connected to the increased international interest in the subject around the beginning of the new millennium, the process moved forward again.

Ultimately, as in any decision making process, Dutch MPA site selection was a matter of choice between alternatives. Both scientists and policy makers sought to come up with information so that the best possible solution could be found. While the basic requirement was that the decision should be based on scientific information of natural values in the North Sea, the scientific study requested by the Dutch government in 2005 shows that the site selection process was one of balancing diverse interests. The alternatives presented in the report described different ways to assess ecological values, but did so explicitly in relation to other (socio-economic) interests at the North Sea. To illustrate this with a few simple examples: the reason why the boundaries of the areas have come out as straight lines on the map (see Fig. 1) are obviously practical rather than based on mere ecological argumentations. Lindeboom and others (2005) state that "we departed from the concept that straight lines [...] are the best approach for future policy and maintenance' (Lindeboom and others 2005, p. 18).
Although this approach seems both pragmatic and commonsensical, it is remarkable vis-à-vis the international obligation of basing site selection exclusively on ecological criteria, without taking future management challenges into account. Important to note also is that the authors are very explicit about the fact that they based the MPA boundaries on a non-scientific, but rather practical, argumentation. A second example is the boundary of the Coastal Zone area, which was set at the $20 \mathrm{~m}$ depth line. While this boundary was determined on the basis of increased natural values for bird and fish species, evidence for increased biodiversity in areas deeper than $20 \mathrm{~m}$ left room for alternative interpretations, pointing to an extended area qualifying for protection (Lindeboom and others 2005, pp. 24-25; 63-67). However, the $20 \mathrm{~m}$ isobath was also of political interest, because of potential spatial conflicts with sand and gravel extraction if the boundary was set further offshore-which was taken into account in deciding on the delineation. A third example comes from the Dogger Bank, for which Lindeboom and others (2005) present different alternatives (Lindeboom and others 2005, pp. 56-57). The Dogger Bank as a whole is a sandbank according to the definition of the Habitats Directive (habitat type 1110) and its area is divided among four EU member states. While the Dutch typically demarcate the edges of this habitat type by following the $20 \mathrm{~m}$ isobath (as mentioned in the EU Interpretation Manual), other member states employ different delineations (Lindeboom and others 2005, pp. 16-56). The German part of the Dogger Bank had already been submitted as an MPA to the EC, and the suggestion was made on the part of the scientists that the Netherlands should follow the German definition of a 'sandbank', which in practice is demarcated by the $40 \mathrm{~m}$ isobath, thereby aligning the borders of the Dutch part with the German part. In this way, the Netherlands would also join up to a larger international plan for the area. These examples show that the ultimate assessment of the boundaries of the five candidate areas in the Dutch part of the North Sea was not based on the ecological evaluation only.

Overall, in managing the informational process, both policy makers and scientists acted as information producers and information users, and tasks were sometimes shared. In some cases, crucial information needed to make important policy decisions was missing and scientists were asked for their expert judgment. At times they were even (literally) asked to speak from their gut, or to voice opinions that consisted of a mix of both scientific and managerial considerations. As scientific information often functions as a legitimating factor in the policy process (in which science is supposed to supply objective truths, and policy makers are expected to act on the basis of objective facts), making use of this kind of more intuitive information can compromise political, as well as scientific, accountability for 
the decisions made. However, now that an integrated approach to marine management is preferred, a closer union of science and policy is also unavoidable. While expert judgment and more intuitive interpretations are an accepted means of dealing with uncertainty and lack of information, making the distinction between fact, expert judgment and gut feeling explicit at all times is considered crucial to safeguard the transparency and accountability of the process.

Interesting to note is that the individuals involved in this particular process, have been working together towards the application of area-based management in the North Sea for years, sometimes even decades (see for instance the bibliographies of the key documents, listed in Table 2). That these people are well acquainted was evident also from the way they referred to each other during the interviews that we conducted. The involved scientists and policy makers clearly have a shared history, they know of each other's hang-ups and points of view, and they have had the chance to build up trust in each other's expertise. This mutual acquaintance also makes possible more strategic ways of managing the science-policy process, and several respondents commented on how deliberate choices were made in involving specific people at certain times, as well as making agreements on each individual's role at different moments in the process (such as explicitly asking someone to not voice a known opinion at a specific meeting).

Moreover, the process was characterized by a certain sense of continuity in more than one way. Comparison of figures presented in this article (Figs. 1, 2, 3, 4), illustrates that scientific information has the tendency to 'stick around'. Without saying that no progress has been made with respect to knowledge development regarding the North Sea environment, the particular site selection (as well as the scientific ecological information supporting it) seems to have remained largely the same. This is underlined by the fact that no new information was produced for the key scientific report in the formal selection process (Lindeboom and others 2005). Whether or not the preselected sites were of special ecological value in general, was not in question.

Of course, this does not imply that information on ecological values was accepted without debate. Contested information concerned for instance the delimitation of boundaries of the sites, as illustrated by differences in size and shape of the areas marked in the four figures. According to an administrative official, the disagreement on geographical specifics was a constraining factor, especially in early stages. Ultimately, it was not until a commonly accepted interpretative framework (as provided by Natura 2000) was established that agreement on particular site selection could be made. The international commitments provided clarity with regard to which selection criteria (and therefore: which kind of information) should be used, after which the particular actors involved settled interactively on how this information was to be valued.

Evidently, information has always been of great importance in decision making on the marine environment, and all interviewees agreed that information played a central role in the designation of MPAs. Some even claimed that it is more formative of the process than political considerations. One of the policy makers stated: 'Politics are of importance for balancing interests, whether a government is leftwing or rightwing matters for a more or less green policy at sea. But if you don't have any scientific information to underpin your decision, it is just based on quicksand. And there are only a few who dare to decide on such a ground'. Yet, we see that in this particular process, particular modes of dealing with lack of data, uncertainties and value-differences were being employed. This has been done explicitly and (inter)actively, such as in the workshops held in preparation of the 2005 scientific report. In this sense, information was used as a resource, but also constituted a structuring force, both constraining and enabling the decision-making process.

\section{Conclusion}

In this article we have discussed the role of scientific information in the MPA selection process in the Dutch part of the North Sea. Given the international requirements that site selection for the future MPA network should be based on scientific ecological criteria only, we started our work for this article in search of a better understanding of the science-policy process involved in meeting this requirement.

To begin with, we have shown that ecological criteria have been central to the Dutch MPA selection process, and that scientific information has indeed played a formative role. Also, scientific information, once taken up into the science-policy process, tends to 'stick around', which is apparent from the fact that the initial set of sites proposed by scientists in the beginning of the nineties bears great resemblance to the set of areas that have now been nominated. However, we have also illustrated that Dutch MPA selection has not been based on ecological criteria alone, and that the exact delimitation of these five sites is the result of a balancing act between ecological, socio-economic and political interests, as well as the explicit anticipation of possible conflicts between natural values and the planning of future socio-economic activities (e.g., the development of extensive wind energy parks at sea, or sand and gravel extraction).

Another conclusion we can draw from our analysis is that especially in cases of uncertainty, or of gaps in the 
available ecological information, the decision making process becomes a close collaboration between scientists and policy makers, in which the latter will sometimes invite the former to suggest a possible course of action for them, based on expert judgment or gut feeling. At times, a situation is created in which the dividing line between the practice of science and that of policy is temporarily crossed, and responsibilities are shared rather than detached. In these cases, it is not always easy to separate ecological, socio-economic, and political considerations, and ad-hoc political decision-making blends with expert judgment.

At the same time, scientists as well as policy makers appreciate the need for science to remain an impartial party in the process. After all, the legitimacy of political action is highly strengthened when based on scientific information that can be regarded as objective and not muddled by other interests. Therefore, while on the one hand the occasional entanglement of science and policy making is accepted as an inherent part of the process, keeping clear the distinctive roles and responsibilities of each is vital.

In this article, we focussed on the interactions between two main actors in the process. We are well aware that a broad range of other actors is involved in marine environmental governance, e.g., NGOs whose role was mentioned only briefly. Likewise, we only focused on the interaction between a select group of involved policy makers and (marine) scientists. Once, in a later stage of the process, management objectives need to be formulated, economic experts will undoubtedly come to play an important role. It has been beyond the scope of this article to closely examine their contributions to the process, but we reckon that this deserves to be further explored.

As a concluding remark, we would like to argue that the wide-spread adoption of the ecosystem approach to environmental management, together with more integrated management styles that are aimed at the long-term, will cause matters of scientific uncertainty and the balancing of different interests to play an ever more dominant role. Therefore, we feel that the specific story that we have presented in this article is not arbitrary, but should be seen as a typical example of present-day environmental policy making in action. This underscores the need to continue to scrutinize the process of information exchange in sciencepolicy interactions.

Acknowledgments We would very much like to thank the people who shared their experience and viewpoints during interviews and conversations. Also, we would like to express our appreciation to anyone who has supplied us with comments and suggestions during the writing process. This effort is part of two $\mathrm{PhD}$ projects, and we acknowledge the support of the involved research institutes: the Amsterdam Institute for Social Science Research (University of Amsterdam) and the Environmental Policy Group at Wageningen University and Research centre.
Open Access This article is distributed under the terms of the Creative Commons Attribution Noncommercial License which permits any noncommercial use, distribution, and reproduction in any medium, provided the original author(s) and source are credited.

\section{References}

Apitz SE, Elliott M, Fountain M, Galloway TS (2006) European environmental management: moving to an ecosystem approach. Integrated Environmental Assessment and Management 2:80-85

Bergman MJN, Lindeboom HJ, Peet G, Nelissen PHM, Nijkamp H, Leopold MF (1991) Beschermde gebieden Noordzee: noodzaak en mogelijkheden. (Protected areas in the North Sea: necessity and possibilities). Report nr. 91(3). Netherlands Institute for Sea Research (NIOZ). Den Burg, Texel, the Netherlands: 1-195

Christiansen S (2009) Towards good environmental status: a network of Marine Protected Areas for the North Sea. WWF Germany. Frankfurt, Germany 1-104

Collins HM, Evans R (2002) The third wave of science studies: studies of expertise and experience. Social Studies of Science 32:235-296

Dane E, Pratt MG (2007) Exploring intuition and its role in managerial decision making Academy of Management Review 32:33-54

de Groot SJ, Lindeboom HJ (1994) Environmental impact of bottom gears on benthic fauna in relation to natural resources management and protection of the North Sea. Netherlands Institute for Sea Research (NIOZ), Den Burg, Texel, the Netherlands, pp $1-257$

Dotinga H, Trouwborst A (2009) The Netherlands and the designation of marine protected areas in the North Sea. Implementing international and European law. Utrecht Law Review 5:23

Douvere F, Ehler CN (2009) New perspectives on sea use management: initial findings from European experience with marine spatial planning. Journal of Environmental Management 90:77-88

Ducrotoy J-P, Elliott M (1997) Interrelations between science and policy-making: the North Sea example. Marine Pollution Bulletin 34:686-701

EC (2007) Guidelines for the establishment of the Natura 2000 network in the marine environment. Application of the Habitats and Birds Directives. European Commission, pp 1-122

Freestone DAC, IJlstra T (1990) The North Sea. Perspectives on regional environmental co-operation. Graham and Trotman, London, UK

Gibbons M (2000) Mode 2 society and the emergence of contextsensitive science. Science and Public Policy 27:159-163

Halffman W (2003) Boundaries of regulatory science: eco/toxicology and the regulation of aquatic hazards of chemicals in the US, England, and The Netherlands, 1970-1995. Dissertation. University of Amsterdam

Hanna SS (1999) From single-species to biodiversity-making the transition in fisheries management. Biodiversity and Conservation 8:45-54

Hugenholtz E (2008) The Dutch Case: a network of marine protected areas. WWF, Zeist, The Netherlands, pp 1-48

ICONA (1992) Noordzee-atlas voor het Nederlands beleid en beheer. (North Sea atlas for Netherlands policy and management). Stadsuitgeverij Amsterdam, Amsterdam

ICONA (1993) De Noordzee, een zee van ruimte? Verslag van een symposium inzake het ruimtelijk Noordzee-beleid gehouden op 24 juni 1992 in het Europa Hotel in Scheveningen. ICONA. Den Haag 
IDON (2005) Integrated Management Plan for the North Sea 2015. Rijswijk, Interdepartmental Directors' Consultative Committee North Sea (Interdepartementaal Directeurenoverleg Noordzee IDON)

IJlstra T, Nollkaemper A (1990) Gebiedsbescherming op de Noordzee. Een analyse van de juridische mogelijkheden en beperkingen. Utrecht, NILOS/Ministerie Landbouw, Natuurbeheer en Visserij

Jak RG, Bos OG, Witbaard R, Lindeboom HJ (2009) Instandhoudingsdoelen Natura 2000-gebieden Noordzee. IMARES rapport C065/09

Jasanoff S (1990) The fifth branch: science advisers as policy makers. Harvard University Press, Cambridge, MA

Jasanoff S (2003) (No?) Accounting for expertise. Science and Public Policy 30:157-162

Knol M (2009) Scientific advice in integrated ocean management: the process towards the Barents Sea plan. Marine Policy 34:252-260

Leslie HM, McLeod KL (2007) Confronting the challenges of implementing marine ecosystem-based management. Frontiers in Ecology and the Environment 5:540-548

Lindeboom HJ, de Groot SJ (1998) Impact-II: The effects of different types of fisheries on the North Sea and Irish Sea benthic ecosystems. NIOZ-rapport 1998:1-404

Lindeboom HJ, Geurts van Kessel AJM, Berkenbosch A (2005) Areas of special ecological values at the Dutch Continental Shelf. Report nr. RIKZ/2005.008/-Alterra Report no. 1203

Margules CR, Pressey RL (2000) Systematic conservation planning. Nature 405:243-253

Mol APJ (2008) Environmental reform in the information age. The contours of informational governance. Cambridge University Press, Cambridge

Mulongoy KJ, Chape SP (2004) Protected areas and biodiversity: an overview of key issues. CBD Secretariat, Montreal, Canada and UNEP-WCMC, Cambridge, UK

Naeem S (2002) Ecosystem consequences of biodiversity loss: the evolution of a paradigm. Ecology 83:1537-1552

NWP (2009) Nationaal Waterplan (National Water Plan). A joint publication of the Dutch Ministries of V\&W, LNV, and VROM. www.nationaalwaterplan.nl

Otway H, Winterfeldt D (1992) Expert judgment in risk analysis and management: process, context, and pitfalls. Risk Analysis 12:83-93

Pauly D, Christensen V, Guenette S, Pitcher TJ, Sumaila UR, Walters CJ, Watson R, Zeller D (2002) Towards sustainability in world fisheries. Nature 418:689-695

PBL (2008) Natuurbalans 2008. Planbureau voor de Leefomgeving. Bilthoven, PBL-publicatienummer 500402008

Pielke RA Jr (2007) The honest broker. Making sense of science in policy and politics. Cambridge University Press, New York
Renn O (1995) Style of using scientific expertise: a comparative framework. Science and public policy. Journal of the International Science Policy Foundation 22:147-156

Rijnsdorp AD, Buys AM, Storbeck F, Visser EG (1998) Micro-scale distribution of beam trawl effort in the southern North Sea between 1993 and 1996 in relation to the trawling frequency of the sea bed and the impact on benthic organisms. ICES Journal of Marine Science 55:403-419

Turnhout E (2003) Ecological indicators in Dutch nature conservation. science and policy intertwined in the classification and evaluation of nature. PhD Thesis. Amsterdam, The Netherlands, Vrije Universiteit Amsterdam

UNEP-WCMC (2008) State of the world's protected areas: an annual review of global conservation progress. In: UNEP-WCMC, Cambridge, UK. http://www.unep-wcmc.org

V\&W (1992) Environmental zoning of the Dutch Continental Shelf, based on ecosystem features. Reference document of the North Sea Water System Plan 1991-1995. Ministerie van Verkeer en Waterstaat (Ministry of Transport, Public Works and Water Management). Report NZ-N-90.07

Van Berkel C, Boon AR, Wiersinga WA (2002) Natuurwaardenkaart Noordzee. Gebieden met bijzondere natuurwaarden op het Nederlands Continentaal Plat. Rapportnr. EC-LNV 2002/115. Expertisecentrum LNV, Ministerie van Landbouw, Natuurbeheer en Visserij. Wageningen

Weingart P (1999) Scientific expertise and political accountability: paradoxes of science in politics. Science and Public Policy 26:151-161

Witbaard R, Bos OG, Lindeboom HJ (2008) Basisinformatie over de Borkummer Stenen, Bruine Bank en Gasfonteinen potentieel te beschermen gebieden op het NCP. Imares rapport C026/08

Worm B, Barbier EB, Beaumont N, Duffy JE, Folke C, Halpern BS, Jackson JBC, Lotze HK FM, Palumbi SR, Sala E, Selkoe KA, Stachowicz JJ, Watson J (2006) Impacts of biodiversity loss on ocean ecosystem services. Science 314:787-790

Yearley S (2005) Making sense of science. Understanding the social study of science. Sage, London

Young OR, Osherenko G, Ekstrom J, Crowder LB, Ogden J, Wilson JA, Day JC, Douvere F, Ehler CN, McLeod KL, Halpren BS, Peach R (2007) Solving the crisis in ocean governance: placebased management of marine ecosystems. Environment 49:20-32

Zevenboom W, Bommelé M, Reuther C (2003) Signalen uit de Noordzee. Signaleren, beoordelen, evalueren en reageren. Report nr. NZ-2003/10. Ministerie Verkeer en Waterstaat, Directie Noordzee, Hoofdafdeling Waterbeheer, Afdeling beleidsvoorbereiding en Evaluatie (AMB), pp 1-39 